A peer reviewed open access journal indexed in NepJol; ISSN 2542-2596

Published by Molung Foundation, Kathmandu, Nepal

Article History: Received on 15 March 2021; Accepted on 31 May 2021

DOI: $\underline{\text { https://doi.org/10.3126/mef.v11i0.37835 }}$

\title{
Breaking the Wall of Poverty: Microfinance as Social and Economic Safety Net for Financially Excluded People in Nepal
}

Karun Kishor Karki, ${ }^{1}$ Nirajan Dhungana, ${ }^{2}$ and Bhesh Bahadur Budhathoki ${ }^{3}$

${ }^{1}$ School of Social Work and Human Services, University of the Fraser Valley, BC, Canada

${ }^{2}$ Nepal Bangladesh Bank Ltd., Kathmandu, Nepal

${ }^{3}$ Department of Business Studies, Indreni Campus, Jhapa, Nepal

\section{Author Note}

${ }^{1}$ Dr. Karun Kishor Karki (D) https://orcid.org/0000-0002-8712-6831

is an assistant professor in the School of Social Work and Human Services, and a Faculty Associate in the Community Health and Social Innovation (CHSI) at the University of the Fraser Valley, British Columbia, Canada. He holds PhD in Social Work from Wilfrid Laurier University, Ontario, Canada. His scholarly inquiries are grounded in critical theories, including anti-racism, anti-colonialism, intersectionality, and anti-oppressive social justice praxis. More precisely, he explores the socio-economic integration the racialized diaspora and minoritized communities, including immigrants, refugees, and LGBTQ+ people in Canada and beyond. 
${ }^{2}$ Nirajan Dhungana is a Branch Manager in a Joint Venture Commercial Bank, Nepal Bangladesh Bank Ltd., Kathmandu, Nepal. He earned a Master's in Finance from Tribhuvan University, Nepal. His research interests involve microfinance, poverty alleviation, economic growth and development.

${ }^{3}$ Bhesh Bahadur Budhathoki is a Lecturer in the Department of Business Studies at Indreni Campus, Jhapa Nepal. He holds a Master's in Business Administration from White House Graduate School of Management, Pokhara University, Nepal. His teaching and research interests include financial intermediation, corporate finance, economics of entrepreneurship, and behavioural finance.

Correspondence concerning this article should be addressed to Dr. Karun K. Karki, School of Social Work and Human Services at the University of the Fraser Valley, 33844 King Road, Abbotsford, British Columbia, Canada V2S 7M8. Email: karun.karki@ufv.ca 


\begin{abstract}
Microfinance is a financial service aimed at economically underprivileged people who have no or limited access to formal financial institutions such as banks due to the lack of financial resources, collateral, or low income. Microfinance institutions provide a collateral-free loan to low-income individuals with the principle of financial inclusion, which allows them to invest in various selfemployment activities. In this article, we critically review the development of microfinance and its issues and challenges in Nepal. More specifically, using the concept of the Grameen Bank model and its relevance in the context of Nepali microfinance institutions, we explore how microfinance can be an effective tool of financial intervention to alleviate rural poverty in Nepal. Methodologically, we utilize secondary data sources such as government and non-government reports and existing empirical studies. We offer recommendations for policymakers to establish appropriate modalities, programs, and microfinance services targeting the socio-economic transformation of rural communities in Nepal. We conclude that the government and financial institutions can stimulate microfinance institutions through multidimensional interventions and facilitation to advance the socio-economic status of financially underprivileged people in rural communities in Nepal.
\end{abstract}

Keywords: Nepal, microfinance, microcredit, rural poverty alleviation, Grameen Bank model 


\section{Breaking the Wall of Poverty: Microfinance as Social and Economic Safety Net for Financially Excluded People in Nepal}

The diverse topography and charismatic features of mountains with flora and fauna make Nepal a naturally beautiful country nestled in the lap of the gigantic Himalayan Range. Unlike its natural beauty, ethnic, linguistic, and social diversity, a large portion of the population is deprived of economic prosperity. Although Nepal has made significant progress in poverty reduction, the country is yet to meet per capita income criteria set by the United Nations to graduate from a least developed country to developing country status. The United Nations Human Development Report (2020) shows that Nepal's Human Development Index (HDI) value has significantly improved since 1990. For example, the HDI value was 0.387 in 2019, whereas it was 0.602 in 2020. This improvement is, in absolute terms, an increase of 55.6 percent. Based on the HDI value, however, Nepal ranked $142^{\text {nd }}$ out of 198 countries and territories. Similarly, the 2020 World Bank report shows a significant gross national income (GNI) per capita. For example, the GNI in 2018 was US\$960, and it increased to US\$ 1,090 in 2019 (Prasain, 2020).

Nepal is making efforts to socio-economic and political transition; however, it needs significant poverty reduction as well. The World Bank (2016) indicates that more than $35 \%$ of the total population in Nepal live in absolute poverty (i.e., the daily earning is less than US\$1 per person). According to a report published in a national daily, The Rising Nepal, the debt liability of the government of Nepal in mid-2020 reached Rs. 1,196 billion, out of which Rs. 482 billion was internal debt and Rs. 714 billion was external debt (Kandel, 2020). While comparing the total debt with the population, the government debt of each Nepali reached Rs. 40,000 (i.e., approximately US\$ 332) per person. In the context of such an economic move, the role of microfinance is pivotal in 
transforming the country's socio-economic status through various microfinance schemes in Nepal.

Microfinance is an integral part of the new economic paradigm, which has significantly contributed to the poorest of the poor through their socio-economic empowerment in society (Bashyal, 2008; Jain, 2020; Khandakar \& Danopoulos, 2004). It provides easy access to financial services to poor people excluded by socalled formal/conventional financial institutions (e.g., banks) due to the lack of collateral or low income (Kasali, et al., 2015; Simkhada, 2018). These financial institutions do not provide loans to people who do not have sufficient assets or income; however, microfinance in this scenario is a practical economic intervention that allows them to access the loan.

Microfinance services exclusively focus on economically deprived people and small entrepreneurs to help them engage in self-employment or other selfearning activities. Further, microfinance services augment social and human capital for financially disadvantaged people and help them move out of the vicious cycle of poverty (Bashyal, 2008; Jain, 2020). Microfinance institutions (MFIs) provide credits to the poor to help the poor set up their income-generating business (Parotid \& Saravan, 2018). Thus, microfinance offers financial liberation for economically vulnerable people and strengthens their sense of dignity through social and economic empowerment.

In this paper, we scrutinized the effectiveness of microfinance services to dismantle the wall of poverty with a view to augmenting the social and economic safety net for financially excluded people in Nepal. More precisely, using the Grameen Bank model as a theoretical tool, we explored how microfinance could be an effective financial intervention to help rural households meet their basic needs and improve their economic welfare. We offered policy recommendations to microfinance institutions (MFIs) to better serve financially impoverished families in rural Nepal. 


\section{Understanding the Microfinance}

Prof. Muhammad Yunus developed the modern concept of microfinance in 1976. He founded the Grameen Bank, an innovative financial microcredit program and microloan to low-income people in Bangladesh. In 1983, the Grameen Bank was authorized by national legislation to operate independently. Microfinance services are designed to provide microloans to financially disadvantaged, socially marginalized, and geographically isolated populations to become self-sufficient by stimulating self-employment generating activities. This innovative concept of the Grameen Bank has been known as 'solidary group lending' to promote savings and investment and alleviate poverty.

Today, this project has received global recognition as a powerful instrument for poverty reduction. For example, the 2019-Microfinance Barometer report indicates that about 140 million microfinance loans had been borrowed globally at the end of 2018 compared to 98 million in 2009. The report also states that $80 \%$ of the borrowers were women in 2018 compared to $65 \%$ in 2009 (Microfinance Barometer, 2019). According to Global Newswire (2020), over 500 million people worldwide directly or indirectly benefited from microfinance services leveraging economic opportunities. It is estimated that global microfinance services may reach US\$313.7 billion by 2025 .

Microfinance is a financial provision that boosts low-income and selfemployed people through accessible and sustainable financial services (Bashyal, 2008; Jain, 2020; Simkhada, 2018). Such services help increase and diversify incomes; build human and social capital, and improve the living standard of poor people (Sharma, 2007). Microfinance services have attained a milestone goal of tackling marginalization and inequality to the financially vulnerable people in most of the least developed countries. Matsangou (2016) states:

Many people living in developing nations are trapped in an endless cycle of poverty, living on very little each day and deprived of regular work and 
access to vital services. Banks are generally unwilling to provide would-be customers with capital in the absence of financial history, collateral, steady employment, or any form of repayment assurance. Yet without access to financial services, there is little hope of escaping. Microfinance aims to bridge this gap (para.7).

Microfinance services are meant to reduce socio-economic challenges to the maximum number of people in need through accessible and sustainable financial services. Such services have supported the poor by reducing their financial crisis, which is a part of their everyday living. Figure 1 shows a global picture of the micro-lending trend (USD in billion) and the number of borrowers (in millions).

\section{Figure 1}

Microlending Landscape 2011-2021

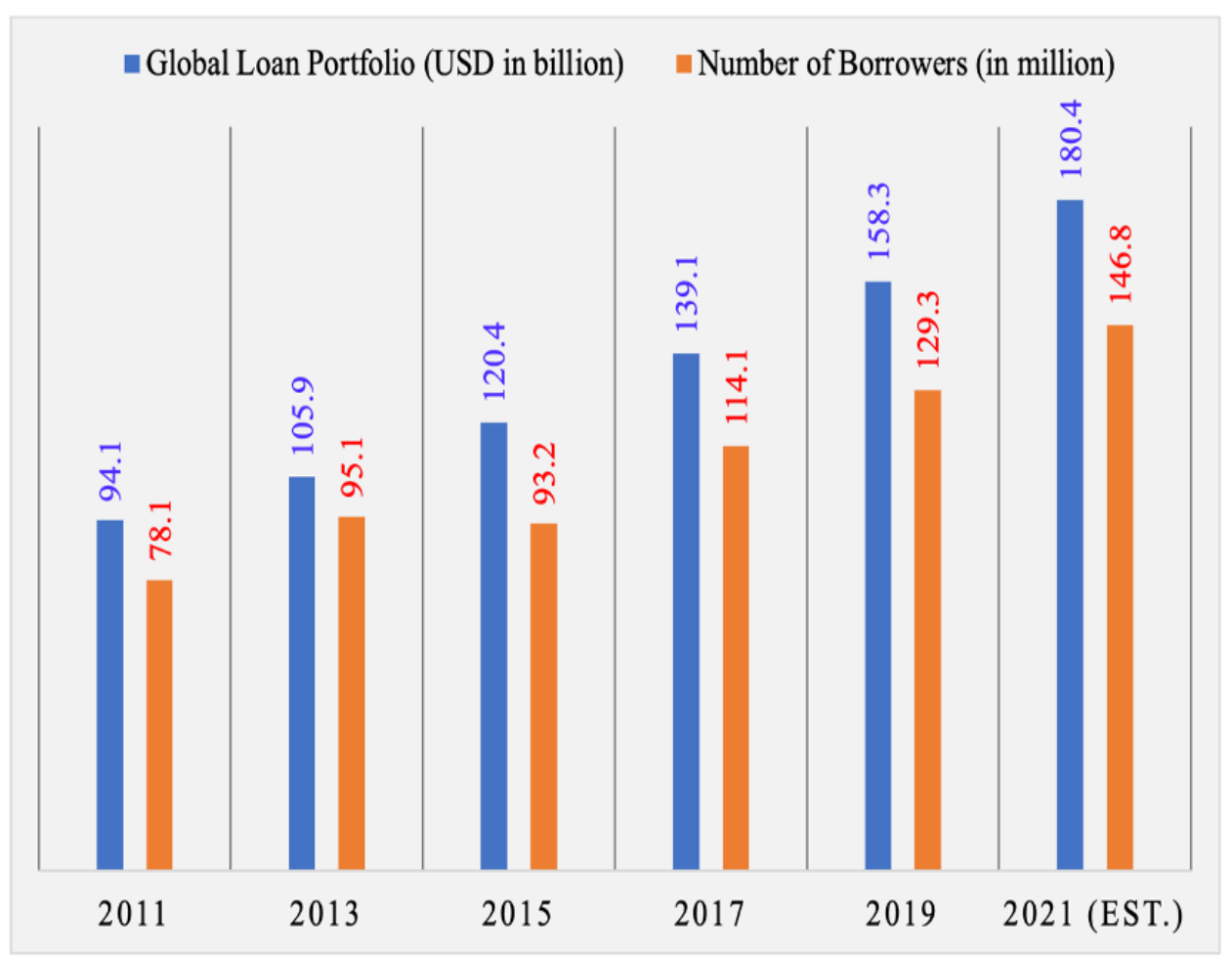

Source: Microfinance Barometer, 2019 


\section{Microfinance in Nepal}

Microfinance is a relatively new phenomenon in Nepal. The Agricultural Development Bank instituted a formal microfinance service by establishing the Small Farmer Development program in 1973. Other Commercial Banks introduced services such as priority area loans, poverty-stricken loans, and loans without collateral; however, these services were less effective. The government of Nepal officially recognized microfinance as a poverty alleviation tool in its Sixth Development Plan from 1980/81 to $1984 / 85$. With the restoration of democracy in 1991, the microfinance sector picked up tremendous momentum. Rural Development Bank contributed to economic mobilization by providing financial access to rural people (Jain 2020). During the early 2000s, many MFIs and NGOs (e.g., Nirdhan Utthan Laghubitta Sanstha, Center for Self-Help) operated under the Grameen Bank model. They instigated microfinance programs and later converted them into Microfinance Development Bank. Similarly, other microfinance development banks (e.g., Chhimek Laghubitta Bittiya Sanstha Ltd.) were established. Further, the Central Bank also licensed Community Based Micro financing NGOs.

Microfinance operates in various models in Nepal. For example, Small Farmer Cooperatives (SFC) operate under the Agricultural Development Bank. Similarly, the Priority and Deprived Sector Credit are mandatory for Commercial banks, Development banks, or Finance companies classified as A, B, or C category of financial institutions. These financial institutions mandatorily invest five percent of their total lending on the priority and deprived sector. Other models, such as Rural Development Banks, Financial Intermediary NonGovernment Organizations (INGOs), are sponsored by donor microfinance programs (Nepal Rastra Bank, 2020).

According to the 2077 BS Unified Directive of Nepal Rastra Bank, MFIs maintain four percent primary capital and eight percent additional capital. The 
Unified Directive also presents the performance and operational figure of 90 MFIs as of Mid- April 2020. The MFIs had the total capital and other reserved funds of Rs. 32,688.64 million, paid-up capital Rs. 20,760.97 million, and total borrowings Rs.145,075.00 million (Nepal Rastra Bank, 2020). Microfinance services have expanded to all 77 districts, with 4,018 branches; 319,201 working centers; 19,058 working staff; 10, 78,820 groups formed by microfinance; and 28, 88,603 borrowers. The total loan comprised Rs.1, 46, 21, 60,550.00 and deposited Rs.11, 29, 33,518.00 as of Mid-April 2020 (Nepal Rastra Bank, 2021).

Although the microfinance program was first introduced in the 1950s in Nepal through cooperatives such as Small Farmers Cooperatives Programs (FSCPs), the operation of microfinance services formally started in 1992 with the establishment of Rural Development Bank, which was based on the Grameen Bank model of Bangladesh (Jain, 2020; Microfinance Industry Report, 2009). With the successful intervention of financial programs, Small Farmers Development Programs were transformed into Small Farmers Cooperative Limited (SFCL) and were self-operated by local farmers. The effectiveness of microcredit services was expanded through various programs such as Priority Sector Lending Program, Production Credit for Rural Women, and Rural SelfReliant Fund (Nepal Rastra Bank, 2021). When the government of Nepal implemented liberal financial policies in 1991, the private sector and NGOs also initiated microfinance programs replicating the Bangladesh Grameen Bank model of microfinance delivery. The most common features of these financial organizations are to increase the outreach of financial services and economic opportunities to poor people to help them become self-sufficient. Microfinance is a segue to promote social and economic development through microentrepreneurs and small businesses. Matsangou (2016) writes:

Many people use the money to start up their first businesses, often mentored by experienced entrepreneurs in their local communities. Or 
they use the money to expand their current businesses, add new products, open new stores, or launch new enterprises in other sectors. This grassroots economic development generates income for the business owners and creates additional jobs for other community members (para. 12).

The role of microfinance is pivotal in alleviating poverty by instigating various microfinance services with a perception of transforming the country's socio-economic condition. The government of Nepal issued a national microcredit policy in 2007 to create conducive financial services and legal measures for MFIs to alleviate poverty.

Microfinance services allow poor people to diversify their financial sources to increase their income. Rural Microfinance Development Centre (2014) conducted a pilot survey in the microfinance service area to measure poverty. The findings show that the poverty rate in the microfinance branch area was lower than the national poverty rate of Nepal (Rural Microfinance Development Centre, 2014). Clients of the microfinance institutions have managed small incomegenerating activities and enterprises (e.g., agro-based, cottage industries, and trade/services) using financial assistance to bridge a cash-flow gap. As the income level among borrowers increases, it also increases their spending power on nutrient food, healthcare services, education, business, and ultimately improving the quality of life (Dhungana et al., 2016; Rural Microfinance Development Centre, 2014). Studies have concluded that the microfinance services have enhanced socio-economic and civic empowerment among women (Dhungana, et al, 2016; Noreen, 2011). Figure 2 below conceptualizes a transmission mechanism of microfinance/ microcredit to poverty alleviation. It demonstrates how microfinance services can help improve the productive capacity, incomeearning opportunities, and livelihood of weaker sections of society by providing 
financial access to enhance their potential ability in income-generating activities and enterprises.

\section{Figure 2}

The Transmission Mechanism of Microfinance/Microcredit to Poverty Alleviation

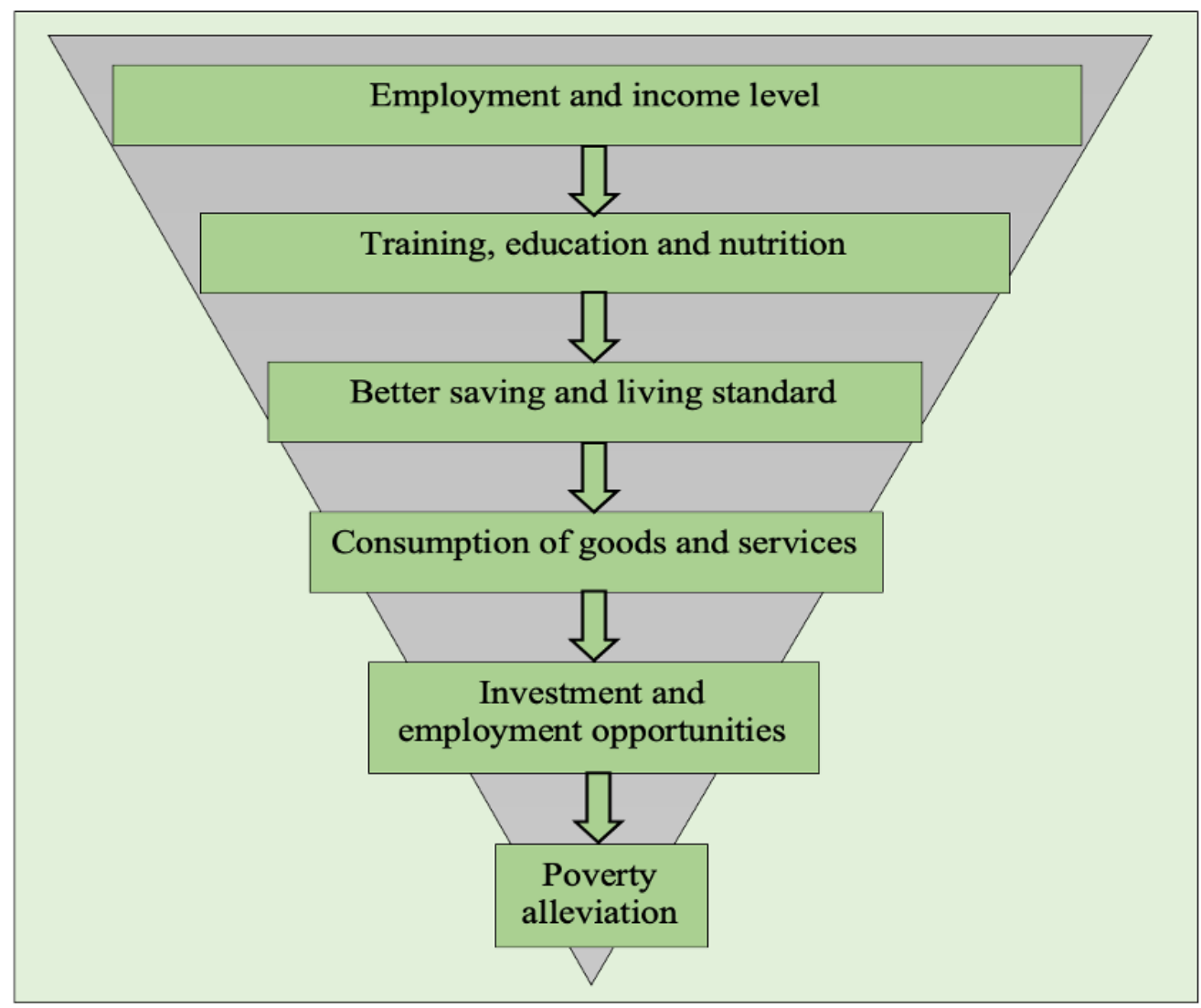

Rajbanshi et al. (2015) investigated the impact of MFIs in Nepal. They concluded that the MFIs exhibited far fewer and more partial effects than are frequently claimed in the industry. In a similar vein, Simkhada (2018) revealed that about $60 \%$ of people were excluded from conventional banks in Nepal due to the lack of proper financial services. He concluded that unless the barrier to financial access is dismantled through policy change (i.e., supply and demand of the service of financial institutions), financial inclusion is difficult to achieve. Simkhada (2013) asserts that cooperatives models effectively serve the financially 
underprivileged people through a wide range of savings and credits, insurance, and non-financial services to rural communities in Nepal.

Microfinance services have positive effects on women's household decision-making (Jain, 2020), women's social and civic empowerment (Noreen, 2011), enabling them for the nutrient food, modern health care service, and quality education of their child (Adhikari \& Shrestha, 2013). Jain (2020) suggested that the microfinance services enabled women empowerment such as household decision-making, major economic decisions, fulfilling family needs, purchasing fixed assets, etc., through savings. The author concludes that, although microfinance services uplifted women's living standards, only a small number of women were utilizing microfinance services. It suggests that the MFIs need to expand their services to better serve the poor communities, particularly women clients in rural Nepal. As outlined above, the following section discusses a theoretical model of the Grameen Bank as a financial intervention to people devoid of banking or credit service.

\section{Grameen Bank Model and Microfinance}

Prof. Muhammad Yunus first introduced the ground-breaking concept of the Grameen Bank model in 1976, with a new vision to offer microcredit or microloan to the poor (Chowdhury \& Somani, 2020; McDonnell, 1999). The philosophy of the Grameen Bank is that all human beings are born entrepreneurs. This innovative project was initiated to test the hypothesis that poor people can generate self-employment at the community level if they get financial services at reasonable interest rates. This hypothesis was experimented with among the poor people in rural Chittagong, and within the groups, the majority were women (Amin \& Uddin, 2018; McDonnell, 1999). The primary purpose of this idea was to free these groups from the clutches of informal moneylenders (Jain \& Mansuri, 2003). Embracing this philosophy, Prof. Yunus provided "collateral-free loans from his pocket to the poor villagers for income-generating activities" such as 
making pots and bamboo couches and chairs (Morduch, 1999, p. 1575). This ground-breaking notion ultimately grew into the Grameen Bank model.

According to the Grameen Bank model, the loan is given to the local villagers in a group voluntarily formed by local people. The members select five persons from their community to make a group. The idea of self-selecting the group members replaces the need for collateral and minimizes the transaction cost (Chowdhury \& Somani, 2020; Hashemi \& Morshed, 1997). Concerning the lending mechanism, the initial two members first receive the loan, followed by the third and fourth members, and finally, the fifth member. If one group member defaults, the entire group members may disqualify subsequent loans. Thus, this mechanism ties all the members together and makes them responsible for properly utilizing the loan in income-generating activities and timely repayments. Figure 3 shows the lending mechanism of the Grameen Bank model.

\section{Figure 3}

\section{Lending Mechanism of Grameen Bank Model}

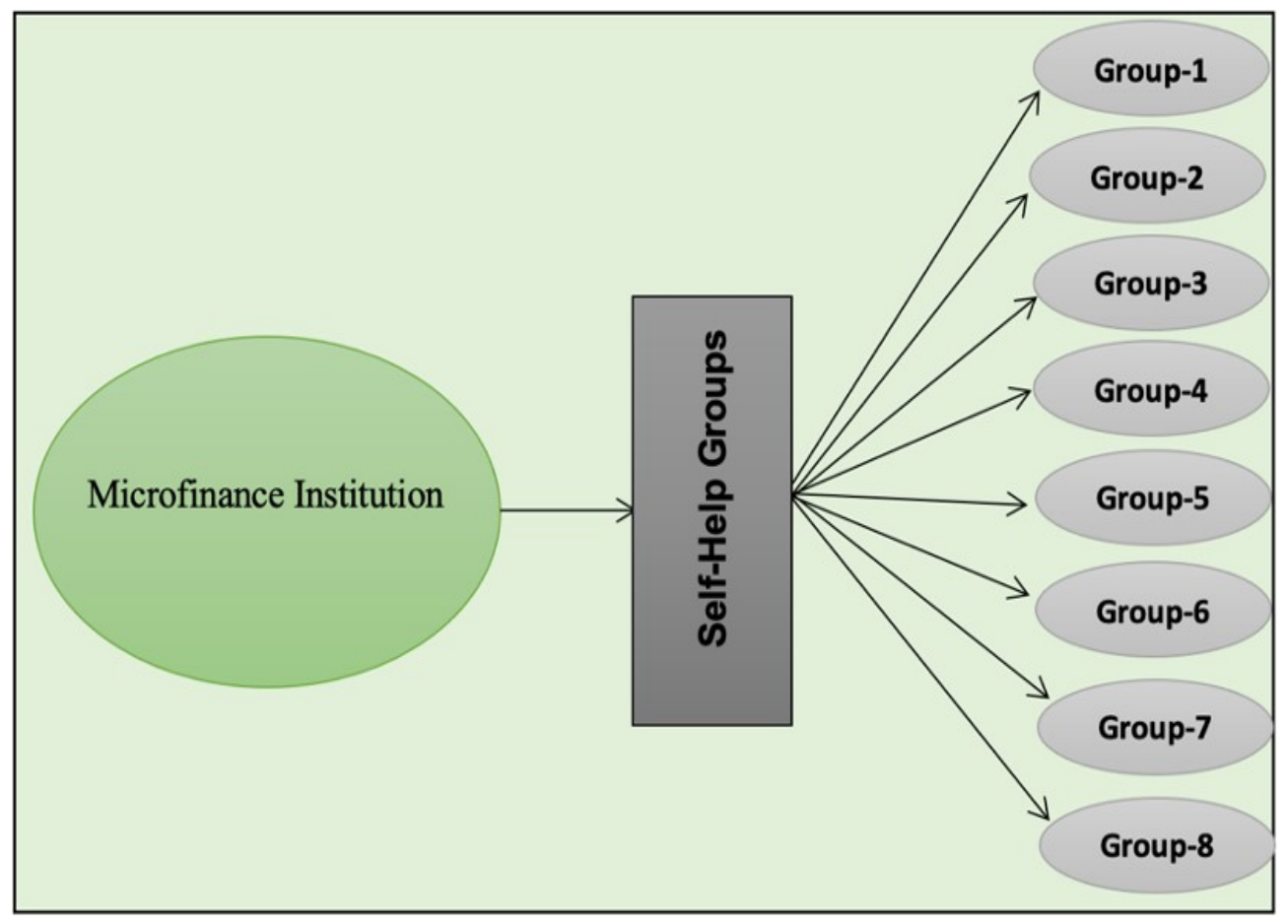


Before the group members receive the loan, they participate in a training program for a week to learn the bank's rules and regulations. The group members discuss their plans, and everyone comes up with the purpose of her/his loan.

Finally, the loan is sanctioned when the bank is satisfied with the proposal and plan of everyone for their investment (see Figure 4).

\section{Figure 4}

\section{Grameen Bank Model of Microfinance/Microcredit}

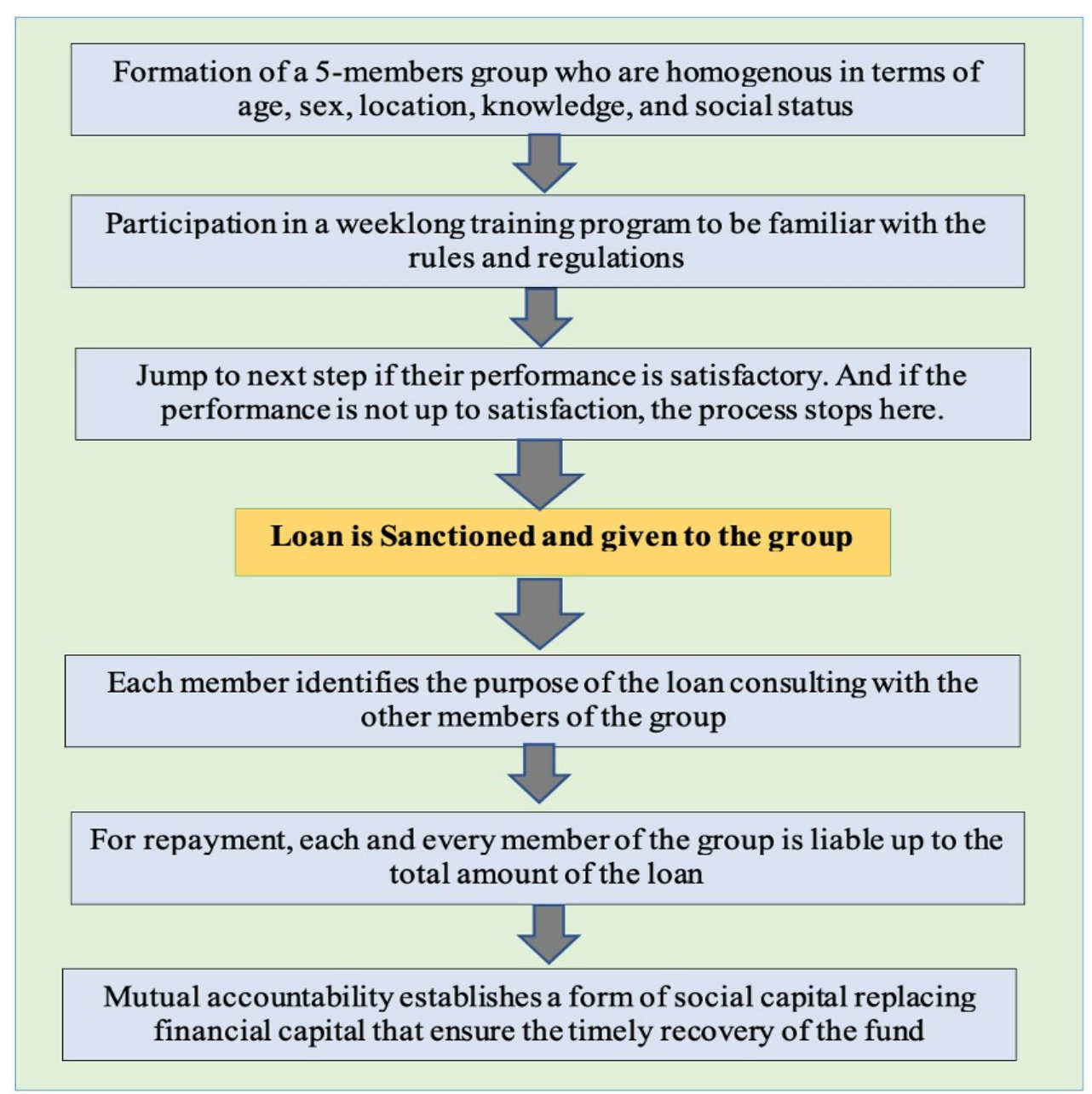

The Grameen Bank model, however, has been criticized widely. For example, the opponents of the model argue that the loans carry unusually high interest rates. In 2015, the National Bureau of Revenue filed a court case against 
Prof. Yunus for evading \$1.5 million in tax (Matsangou, 2016). In Aljazeera, DeCrow (2019) reports that Sheikh Hasina, the Bangladeshi prime minister condemned MFIs for "sucking blood from the poor in the name of poverty alleviation" (para. 9). Furthermore, it is also criticized that some MFIs are focused on profit maximization rather than serving the poorest of the poor. For example, Matsangou (2016) writes:

A new trend [has] emerged in the world of microfinance...not just to help others but also to profit. The likes of Barclays, CitiGroup and General Electric initiated microfinance projects that gained from lending small amounts of capital to so-called unbankable (para. 17).

The opponents have raised the issue of monitoring mechanisms. They have questioned if the financially excluded people could be pulled out of the cracks of the debts through the financial intervention of microfinance.

The Grameen Bank policy found that the repayment rates are higher if the groups are relatively homogenous, i.e., comprising of members from similar socio-economic backgrounds, same-sex, and from the same village, than the groups that are formed based on a bank's administrative decision (Grameen Bank, 2011; Huppi \& Feder, 1990). Self-selected group members have several advantages because of collective responsibility and joint liability, such as higher success rates of loan repayment, successful peer monitoring, and low credit risks (Grameen Bank, 2011).

Chowdhury and Somani (2020) found recovery rates of 94.5\% in 2018. The trend of Grameen Bank policy often targets microfinance services to women, in some cases exclusively. For example, Daley-Harris (2007) reports that $85 \%$ of the most indigent microfinance clients were women. Thus, focusing on female clients makes sense from the public policy perspective not because women are particularly vulnerable and careful investors and have registered higher repayment rates. In the context of Nepal, it is often the situation that rural women rarely 
leave the village compared to their male counterparts. The Grameen Bank model substantially contributes to financially impoverished people, including women, through its microfinance services.

\section{The Grameen Bank Model and Nepali MFIs}

The Grameen Bank model is a foundation for a lending mechanism of the MFIs in Nepal; however, they do not necessarily embrace the theoretical underpinnings of the model. For example, the group mechanism or provision in the Grameen Bank model (see Figure 3), which consists of five members in a group and eight such groups, does not necessarily apply in the context of Nepali MFIs. The group formation is flexible, i.e., three to twenty-five members in a group (a personal conversation with Mr. Basanta Lamsal, Chief Executive Officer, Vijaya Laghubitta Bittiya Sanstha Ltd, May 2, 2021). The rationale for group flexibility is customers' interest, low density of population in rural areas, and competition among MFIs.

Similarly, according to the Grameen Bank model, the group members are voluntarily formed; however, in Nepali MFIs, the staff members and clients play a proactive role in selecting quality members. The loan disbursement mechanism is also different in Nepal than introduced in the Grameen Bank Model. In Nepali MFIs, the loan is generally disbursed to group members in three distinct phases with a ratio of $40 \%, 40 \%$, and $20 \%$, respectively. In the case of a small group, this mechanism may not apply. As introduced in the Grameen Bank model, the entire group members will be disqualified for the loan if one of their members defaults on the loan repayment. However, in the context of Nepal, it does not necessarily apply, and so does the case for the requirement of eight groups (a personal conversation with Mr. Debendra Bahadur Shah, Deputy Chief Executive Officer, Kisan Laghubitta Bittiya Sanstha Ltd., May 2, 2021).

According to Nepal Rastra Bank's Unified Directive (2077BS), MFIs can approve a maximum of Rs.5, 00,000.00 loan to an individual without collateral 
and Rs.7, 00,000.00 to individuals who are not involved in groups taking collateral. Similarly, a maximum of Rs. 15, 00,000.00 loan can be sanctioned to individuals after two years whose performance falls under the underpass category in the past two years. However, if the client is involved in a group, he /she can't get both collateral-based and group guarantee-based loans from MFIs in Nepal (Nepal Rastra Bank, 2020). This suggests that the credit policy and guidelines of MFIs in Nepal are more flexible than the fundamental provision of the Grameen Bank model.

\section{Issues and Challenges of Microfinance Institutions (MFIs) in Nepal}

Microfinance is now globally acknowledged as a powerful financial tool to fight against poverty. Its innovative management and business strategies helped people move out of poverty in many third-world countries. While an effective intervention of microfinance services has touched low-income families, the success rate isn't the same everywhere (Basnet, 2007). In Nepal, microfinance hasn't been as successful as it has been in Bangladesh, India, South America, and Africa. For instance, in Bangladesh, the microcredit organizations have reached almost $90 \%$ of villages, where more than $75 \%$ of low-income families are directly benefited, and among them, 95\% of borrowers are women (Grameen Bank, 2011). On the other hand, in Nepal, a decade-long Maoist insurgency (1996-2006) created an unfavourable climate for small businesses, which could otherwise penetrate the more impoverished strata in the rural communities in Nepal. The political crisis resulted in financial deprivation among many people in rural communities.

The large number of MFIs has increased since the early 2000s; however, most of them are concentrated in urban cities or densely populated areas, where there is easy proximity to the market. The MFIs have grossly neglected the neediest rural communities in the hills and mountain areas. The Microcredit programs target low-income families; however, they serve less poor or 
disadvantaged groups (Sharma, 2007). This shows that the poorest of the poor, who are the highest priority of the government of Nepal, are less benefited from the microfinance services.

Many MFIs have formed groups for savings and credit purposes. Despite their focus on landless or disadvantaged groups, in some cases, it is found that groups are formed mostly with non-poor people, and the group leaders are selected from well-to-do families. While many poor people have started microenterprises using their loans taken from MFIs, many face marketing problems for various reasons, including selecting inappropriate products, limited knowledge on managing the business, and lack of experience. Similarly, the lack of advanced technology in the agricultural sector, particularly in rural areas, hinders the effectiveness of microfinance services. Additionally, the market for agricultural production is constrained due to high transportation costs in the hills or mountain regions. Political instability has been another concern, which has created economic insecurity and paralyzed the business prospects of MFIs in Nepal.

It is often criticized that many MFIs lack professionalism within financial institutions. Many MFIs have been mushrooming every day; however, lack of knowledge and business plans are significant concerns for running financial programs and sustainability. Credit customer duplication is another challenge to MFIs in Nepal. As per Nepal Rastra Bank Directive, no 3/077-2 “Ja," for D class institutions, multiple banking customers should be confirmed by taking credit information from Credit Information Center (CIC). Although MFIs take customer declarations about various banking facilities to avoid duplication, some customers hide their information about loans from multiple banks to borrow more loans. This is due to the lack of coordination among MFIs to collect clients' credit information. As a result, the same loan can likely be financed from multiple MFIs. This results in bad debt loans to clients due to their limited income source for loan repayments. 
There is a diminishing attraction of customers to MFIs due to high interest rates, high service charges, lack of synchronization between cash flow from the business and repayment schedule of the loan, group members' responsibilities, and rumour of exploitation by MFIs. These all result in customer turnover in MFIs in Nepal. Microfinance institutions need to deconstruct these challenges for sustainability in the business. Further, MFIs have inadequate resources for investment. For example, Nepal Rastra Bank Directives has stated that MFIs can mobilize their financial resources 30 times of their core capital; however, microfinance is restricted to mobilized public deposits unless approved by Nepal Rastra Bank. There are currently only a handful of MFIs, which can mobilize public deposits. Hence MFIs are unable to expand their business in rural and mountain regions.

Alleviating poverty is quite challenging. Microfinance institutions need to put their every effort into economically marginalized and vulnerable groups in rural communities. Central Bank Directives has made a mandatory legal provision to $\mathrm{A}, \mathrm{B}$, and $\mathrm{C}$ category Banks and Financial institutions to invest $5 \%$ of total investment in economically marginalized and disadvantaged groups (Nepal Rastra Bank, 2021). Yet, the definition of economically marginalized people is not in an economic term or income threshold. When there is no clear threshold, the microfinance services may not reach the targeted groups.

\section{Discussion and Policy Implications}

Although the microfinance program can have a powerful impact on rural poverty alleviation, it is not a panacea. Several other factors hinder development policy and implementation, which need to be addressed appropriately and adequately. Extensive evidence discussed above demonstrated that microfinance is a practical financial intervention to reduce the poverty and vulnerability of lowincome families in developing countries. MFIs play a significant role in empowering women by increasing their contribution to managing household 
emergencies and controlling decision-making. Microfinance services improve nutrition, maternal and child health, and housing, especially among children and women.

In the Nepali context, however, decades of experience have demonstrated that progress in these areas is precarious due to political volatility, economic insecurity, and lack of basic infrastructure in rural communities in Nepal (Dhakal, 2010). This is imperative that a strong management and efficient operation of microfinance programs is required to reach financially deprived people in the rural communities in Nepal. In a developing country like Nepal, where the private sector is weak, the government has a significant role in promoting MFIs through multidimensional interventions and facilitation. This section discusses policy implications and recommendations directed towards policymakers to establish appropriate microfinance programs and services targeting the socio-economic transformation of rural communities in Nepal.

\section{Need of a National-level Microfinance Policy}

The government should develop a national-level microfinance policy identifying appropriate modalities to direct the microfinance programs and accomplish the specified objectives. Such programs should emphasize vocational and skill enhancement training to enhance borrower entrepreneurship and business management skills. Further, the policy requires collaboration between provincial and municipal governments and non-governmental institutions. The existing outreach of microfinance services is minimal. It has been witnessed that MFIs cannot be extended comprehensively without the political stability in the country. To better serve financially underprivileged people, the government should develop a long-term policy through the existing network of MFIs. The government should invest in infrastructure such as motorable roads in rural areas and ensure transportation facilities even in the rainy season in the hilly and mountainous regions. 


\section{MFIs to Focus on Rural Communities}

Many MFIs are in urban cities and district headquarters. They are mainly concentrated in the Terai and hilly urban areas. The mountain and rural hills are grossly neglected. The government should design and implement special programs to motivate the MFIs for rural communities in mountain and hill regions. MFIs should promote the local NGOs and Cooperatives to launch localoriented and lucrative programs. The government of Nepal should give tax exemption, additional subsidy package, interest-free fund to MFIs operating in rural hills and mountain regions. Thus, MFIs should be encouraged to extend their services into rural areas to serve more impoverished clients.

\section{Promoting Agriculture and Agro-processing}

In Nepal, poverty is concentrated more in rural areas. Thus, the intervention becomes pragmatic if it is started from agricultural, agro-based, and natural resource-based enterprises. The poor are attached more directly to livelihood, be it a farmer, an unskilled wage earner, or an entrepreneur. Promoting agriculture and agro-processing in an agricultural country like Nepal is crucial in enabling the microfinance sector. Almost two-thirds of the industries are agroindustries, and processing is in the initial stage in Nepal (Kayastha, 2013). This sector lags the production growth and suffers from a lack of entrepreneurial skills and a semi-skilled workforce, as indicated earlier. Capacity building in this sector is also needed through a broader perspective. Similarly, the microfinance sector also lags agro-processing and cold storage in the local areas to provide a smooth market mechanism to sell the products produced by the borrowers for a reasonable price.

\section{Sustainable Availability of Funding}

Sustainable availability of funding for MFIs is a prime factor of attention for promoting them. Self-generated funds within are inadequate as the saving capacity of the poor is small. Government policy directives to persuade banking 
and finance institutions to lend some proportion in deprived sector credit is the right direction. Such policy increases the supply of MFI funds significantly as the banking sector's lending resources are extensive. However, the banking approach of just setting aside funds is inadequate to drive MFIs without persuasion to right portfolio prioritization and addressing of the issues. Thus, to promote MFIs, the provision of insurance and other alternatives have to be there as a backup policy. In doing so, Nepal Rastra Bank can play a crucial role by increasing paid-up capital or merging MFIs to mobilize public deposits.

\section{Capacity-building Support}

Capacity building is a crucial aspect of microfinance for its services and users. Information generation, entrepreneurship development, project and viability analysis, marketing arrangement, group formation and mobilization, adoption of disciplines, account keeping, computer operations, social activities to enhance human capacity, understanding of borrowers, etc., are the most critical areas to consider. Likewise, promoting microfinance is closely linked to micro-enterprises and entrepreneurship beyond primary sectors such as processing of various smallscale agro-products and agro-processing, as discussed earlier. The government should arrange resources and support MFIs for capacity building through skillbased training, advancement of digital technology, and credit facilitation.

\section{Nepal Rastra Bank to Develop Regulatory Mechanisms}

Nepal Rastra Bank should monitor the problem of loan client duplication and take initiatives to implement an effective way of collecting credit information systems of microfinance so that it decreases the duplication problem of multiple financing and reduces bad debt loans due to duplication of credit customers in MFIs. The regulatory body of banks and financial institutions should be aware about the poorest of the poor to whom the deprived and priority sector loan has been designed to pull out of poverty. The government also should maintain the 
income and economic status by establishing a clear income threshold and criteria so that MFIs can easily select a targeted group of people to serve them better.

Additionally, Nepal Rastra Bank should issue the circular to all the Banks and Financial Institutions (BFIs) to reduce complex and lengthy documentation procedures and adopt a cost-effective loan process for deprived and priority sector loans. The competent authority has been recommended to waive the charge on the issuance of documents for the Deprived Sector Loans. There is a broader consensus about microfinance programs not penetrating the neediest clients due to resource constraints. Higher interest rates and service charges result in a higher customer turnover rate. Nepal Rastra Bank should strengthen MFIs and allow them to mobilize public deposits, which eventually helps overcome resource constraints, reduces the cost of funds, and enables them to offer competitive interest rates. This can create a healthy environment for MFIs to alleviate rural poverty in Nepal.

\section{Conclusion}

Microfinance can be an effective financial intervention to alleviate rural poverty by creating employment and self-employment opportunities in Nepal. It provides collateral-free loans to low-income people neglected by so-called formal financial institutions such as Commercial Banks, Development Banks, and Finance Companies. Although MFIs are working to uplift the financially underprivileged people, more work is needed to penetrate the poorest of the poor strata of the rural communities in Nepal. Moreover, the Nepali economy is primarily agriculture-based, but the progress in the agricultural sector is low. Until the microfinance services are targeted to this sector, it is challenging to improve rural people's substantial economic and social apparatus in Nepal. This indicates the need for a particular strategy in microfinance to minimize headcount poverty through financial intervention in a rural community in Nepal. 
The Grameen Bank model is the basis of Nepali MFIs. It used to be a very effective and popular model in the past. Recently, the relevance of the model (group solidarity model) is diminishing due to changes in the social dynamics and social harmony. Further, microfinance clients want to be independent and do not want to take responsibility for others. There are strong voices of clients for individual products rather than group products based on group guarantee and responsibility for a loan. Therefore, the demand for collateral-based individual loans and individual-based non-collateral loans is increasing rapidly in the microfinance industry in Nepal. This mechanism also reflects that the credit policy and guidelines of MFIs in Nepal are more flexible than the fundamental provision of the Grameen Bank model. Thus, well-designed microfinance programs with appropriate product designs are warranted to serve the financially marginalized rural communities. Such programs should target a wide range of social and economic indicators, including income, nutritious food, housing, education for children, health care, and women empowerment. These indicators form the thrust of this vital mission that microfinance is one steppingstone of rural poverty alleviation in Nepal.

\section{Acknowledgements}

We would also like to thank the three anonymous reviewers of this paper for their insightful comments on the earlier version of this article, which has helped strengthen and clarify our arguments.

\section{Declaration of Conflicting Interests}

We declared no potential conflicts of interest concerning the research, authorship, and/or publication of this article.

\section{Funding}

We received no financial support for the research, authorship, and/or publication of this article. 


\section{References}

Adhikari, D. B., \& Shrestha, J. (2013). The economic impact of microfinance in Nepal: A case study of the Manamaiju Village Development Committee, Kathmandu. Economic Journal of Development Issues, 15(1), 36-49.

Amin, F. B., \& Uddin, S. J. (2018). Microfinance-economic growth nexus: A case study on Grameen Bank in Bangladesh. International Journal of Islamic Economics and Finance, 1(1), 1-19.

Bashyal, R. (2008). Microfinance: Access to finance for Nepal's rural poor. Institute for Integrated Development Studies. https://www.econbiz.de/Record/microfinance-access-to-finance-fornepal-s-rural-poor-bashyal-rama/10003783371

Basnet, X. (2007). Microfinance programs and their challenges in Nepal. http://econ.duke.edu/uploads/assets/dje/2007_Symp/Basnet.pdf

Chowdhury, T. A., \& Somani, S. (2020). Performance evaluation and impact of Grameen bank on social development and women empowerment in Bangladesh. International Journal of Social and Administrative Sciences, 5(1), 54-73.

Daley-Harris, S. (2007). State of the microcredit summit campaign report 2007. http://www.promujer.org/publications/our_publications_4_Pdf_EN_SO CR07_Eng.pdf

DeCrow, J. (2019, November 3). Bangladesh court grants bail to Nobel laureate Muhammad Yunus: Micro-credit pioneer appears in court over-firing three employees by Grameen Communications, where he is chairman. https://www.aljazeera.com/news/2019/11/3/bangladesh-court-grantsbail-to-nobel-laureate-muhammad-yunus 
Dhakal, N. H. (2010). Microfinance and local economic development in Nepal. http://www.cednepal.org.np/files/listingfiles/Microfinance\%20and\%20P overty\%20Reduction.pdf

Dhungana, B. R., Singh, J. K., Acharya, D., Gautam, S., \& Paudyal, P. (2016). Perceived usefulness of a microfinance intervention on health awareness and practices in Nepal. Frontiers in Public Health, 3(289), 1-7.

Global Newswire (2020, September 4). Global microfinance industry. https://www.reportlinker.com/p05799111/Global-MicrofinanceIndustry.html?utm_source $=\mathrm{GNW}$

Grameen Bank (2011, September 6). Grameen Bank at a glance. https://www.youtube.com/watch?v=MgYes4bA7oM

Hashemi, S. M., \& Morshed, L. (1997). Grameen Bank: A case study. In G. D. Wood, \& I. A. Sharif (Eds.), Who needs credit? Poverty and finance in Bangladesh (pp. 217-230).

Huppi, M., \& Feder, G. (1990). The role of groups and credit cooperatives in rural lending. The World Bank Research Observer, 5(2), 187-204.

Jain, B. K. (2020). Microfinance services and women empowerment in Biratnagar metropolitan, Nepal. Journal of Underrepresented and Minority Progress, 4(2), 251-270.

Jain, S., \& Mansuri, G. (2003): A little at a time: The use of regularly scheduled repayments in microfinance programs. Journal of Development Economics, 72(1), 253-279.

Kandel, B. (2020, June 24). National debt situation of Nepal. The Rising Nepal. https://risingnepaldaily.com/opinion/national-debt-situation-of-nepal Kasali, T. A., Ahmad, S. A., \& Lim, H. E. (2015). The role of microfinance in poverty alleviation: Empirical evidence from South-West Nigeria. Asian Social Science, 11(21), 183-192. 
Kayastha, R. (2013). Current issues of microfinance in Nepal. Yokohama Journal of Social Science, 18(3), 71-83.

Khandakar, E., \& Danopoulos, C. P. (2004). Microfinance and third world development: A critical analysis. Journal of Political and Military Sociology, 32(1), 61-77.

Matsangou, E. (2016, November 16). Why the microfinance model won't solve the global poverty crisis. https://www.worldfinance.com/specialreports/why-the-microfinance-model-wont-solve-the-global-povertycrisis

McDonnell, S. (1999). The Grameen Bank microcredit model: Lessons for Australian Indigenous economic policy. http://caepr.anu.edu.au/Publications/DP/1999DP178.php

Microfinance Barometer (2019). Ten years already! A look back at the trends in microfinance. https://www.convergences.org/wpcontent/uploads/2019/09/Microfinance-Barometer-2019_web-1.pdf

Microfinance Industry Report (2009). Banking with the poor network. https://www.yumpu.com/en/document/view/49077907/microfinanceindustry-report-nepal-banking-with-the-poor-network

Morduch, J. (1999): The microfinance promise. Journal of Economic Literature, 37(4) 1569-1614.

Nepal Rastra Bank (2020). Unified directive - 2077BS. https:/www.nrb.org.np/contents/uploads/2020/10/UD-D-classfinall1.pdf

Nepal Rastra Bank (2021). Microfinance institutions supervision department. https://www.nrb.org.np/departments/mfd/

Noreen, S. (2011). Role of microfinance in the empowerment of the female population of Bahawalpur district. International Conference on Economics and Finance Research, 4(20), 65-71. 
Prasain, S. (2020, July 3). Nepal moves up to a lower-middle-income country, says World Bank report. The Kathmandu Post. https://kathmandupost.com/money/2020/07/03/nepal-is-now-officiallya-lower-middle-income-country-the-world-bank-says

Purothit, B. C., \& Saravan, S. (2018). Sustainability and efficiency of microfinance institutions in South Asia. Theoretical and Applied Economics, $X X V(4), 93-116$.

Rajbanshi, R., Huang, M., \& Wydick, B. (2015). Measuring microfinance: Assessing the conflict between practitioners and researchers with evidence from Nepal. World Development, 68, 30-47.

Rural Microfinance Development Centre (2014, April). Microfinance: Newsletter of rural microfinance development center Ltd. http://www.rmdcnepal.com/uploads/financials/English\%20Newsletter\% 2024,\%20April\%202014.pdf

Sharma, P. R. (2007). A comparative study of microfinance in Nepal and Bangladesh. http://www.microfinancegateway.org/gm/document1.9.45562/a\%20comparative $\% 20$ study $\% 20$ of $\% 20$ microfinance.pdf

Simkhada, N. R. (2018). Approaches and design of microfinance programs for the ultra-poor in Nepal. Enterprise Development and Microfinance, 29(3-4), 276-286.

Simkhada, N. R. (2013). Problems and prospects of the cooperative sector in Nepal for promoting financial inclusion. Enterprise Development and Microfinance, 24(2), 146-159.

United Nations Human Development Report (2020). The next frontier: Human development and the Anthropocene. http://hdr.undp.org/sites/all/themes/hdr_theme/country-notes/NPL.pdf World Bank (2016). Moving up the ladder: Poverty reduction and social mobility in Nepal. https://openknowledge.worldbank.org/handle/10986/25173 